Omar Aziz, Matthew Gibbons, Chris Ball and Emma Gorman

\title{
The Effect on Household Income of Government Taxation and Expenditure in 1988, 1998, 2007 and 2010
}

Introduction

Governments change the resources available to households through both spending and taxation. This article examines the extent to which the government redistributes from highto low-income households, and how this has changed since 1988. As well as covering market outcomes and the effects of personal income tax and cash benefits on the disposable incomes of households, the distribution of indirect taxes and of government expenditure on in-kind social services is calculated. The results reveal how government affects the distribution of post-tax income received by households, when income is defined considerably more broadly than usual. This article extends Treasury's previous fiscal incidence study of 1988 and 1998 using 2007 and 2010 data. ${ }^{1}$

Omar Aziz, Matthew Gibbons, Chris Ball and Emma Gorman are employed by the New Zealand Treasury.
The following section defines the three concepts of income discussed in this article. Some of the main demographic, economic and policy changes that have affected household incomes and government expenditure since 1988 are then summarised. The data and methods are then outlined. The focus then switches to the distribution of different types of household income and the incidence of government expenditure and taxation. The final section calculates the net fiscal impact of government expenditure, and the redistributive effects of this expenditure on the Gini coefficient.

Three concepts of income

Figure 1 outlines the three concepts of household income included in fiscal incidence studies. Market income is income from wages and salaries, investments, selfemployment, and from other forms of taxable income earned by private means. Disposable income is market income plus cash benefits, housing subsidies and pensions, but less income tax payments. However, studies of market and disposable income exclude the important distributive effects of in-kind provision 
Figure 1: Three definitions of household income

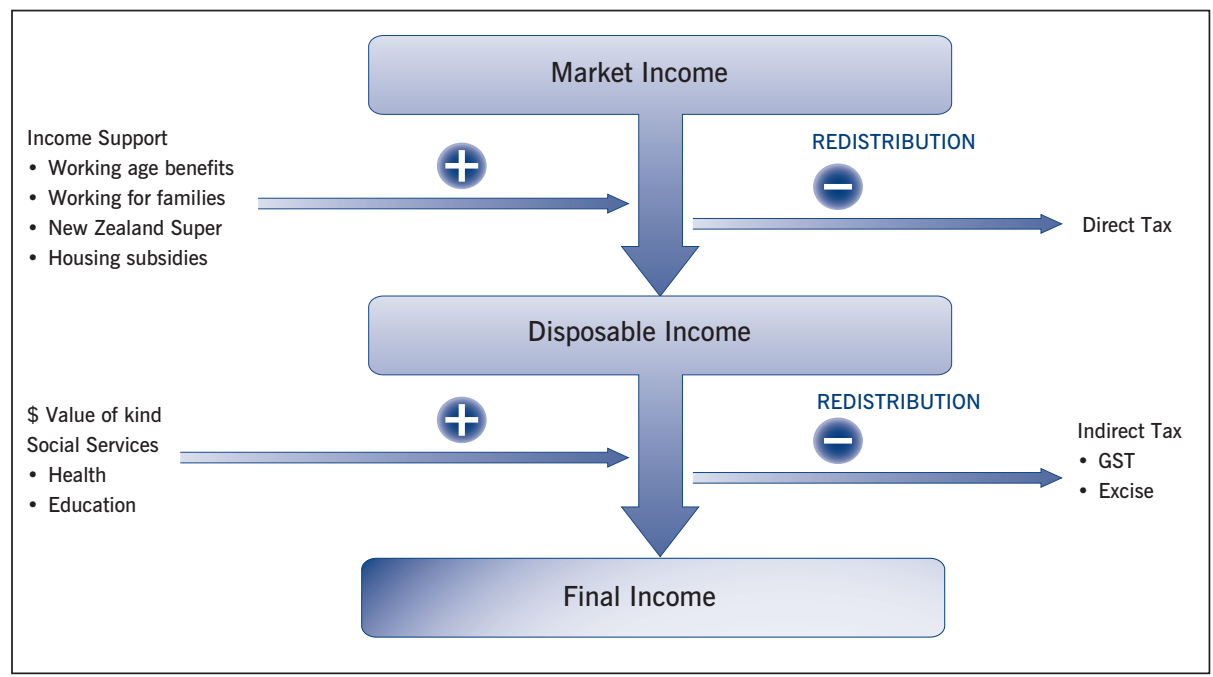

of government services and the effects of indirect taxes. Fiscal incidence studies therefore investigate the distribution of final income.

Final income is disposable income plus the cost of subsidised or free health and education services, but less indirect tax payments (Harding, Lloyd and Warren, 2006, 178). By including a higher proportion of government expenditure and taxation than disposable income, fiscal incidence studies provide a broader and more comprehensive picture of the economic situation of households and of a society's resource distribution. Usually about $60-70 \%$ of government expenditure and taxation are included, with company tax and many types of government expenditure being excluded (Australian Bureau of Statistics, 2007; Barnard, 2009).

Because of the information provided on the distributional impact of government spending and taxation, statistics agencies in Britain and Australia conduct regular fiscal incidence studies. Increasingly governments are also using the results when making taxation and spending decisions.

Fiscal incidence was first quantified in New Zealand during the 1980s (Department of Statistics, 1990; Snively, 1986). In a Treasury study, Crawford and Johnston in 2004 found that for all income deciles the real final incomes of households were, on average, at least the same in 1998 as in 1988, and in most cases had increased. Government intervention, through taxes, cash benefits and social services, had maintained the incomes of households in less well-off deciles over a period when market incomes had become less equal (Crawford and Johnston, 2004, 30). Because no studies of fiscal incidence in New Zealand using survey data have been undertaken since, there is no up-to-date information on final income distribution.

Changes in the fiscal incidence of government expenditure can occur for a number of reasons, including policy and demographic reasons. The next section outlines some of these reasons.

\section{Changes in New Zealand's economy, population structure and government policies}

Fiscal incidence research in New Zealand has taken place against a background of changes in the economy, labour market, population structure, technology, people's expectations and government policies. For instance, changes in the rate of unemployment and benefit receipt have affected income distribution and government expenditure. The number of people receiving the unemployment benefit was 87,000 in 1988; grew to 158,000 in 1998 , following a period of economic restructuring; fell to 39,000 in 2007 after a period of sustained economic growth; but then increased to 76,000 in 2010 because of an economic downturn (Ministry of Social Development, 2011, 13-14). The number of people receiving sickness and invalid's benefits and the domestic purposes benefit has increased. Nevertheless, the proportion of $\mathrm{New}$
Zealanders receiving working-age benefits was lower in 2010 than during the high plateau that occurred between about 1990 and 2000 (Welfare Working Group, 2011, 43).

Market and disposable income, and to a lesser extent consumption of market goods, are less equally distributed in New Zealand now than in the mid-1980s (Perry, 2011, 167; Stillman et al., 2011, 6). An increase in income inequality has occurred in almost all developed countries since the 1980s. However, lower unemployment and greater targeting of income transfers and income tax have sometimes stabilised or reversed this trend in some countries (OECD, 2008, 27-34).

Partly because of greater demand for skilled workers, the percentage of New Zealand's population aged 15 and over who were participating in some form of tertiary education more than doubled between 1988 and 2010. Participating in further education temporarily depresses people's income, but usually has a longterm pay-off for them. Similarly, usage of early childhood education services has grown, reflecting greater participation by women with young children in the workforce, the wider availability of services and changed attitudes towards these services (May, 2009).

The New Zealand population has been gradually ageing, with the proportion of people aged over 65 growing from $10.7 \%$ of the population in 1988 to $13 \%$ in 2010 (Statistics New Zealand, 2010a). An ageing population can increase demand for health services, although increased expectations of service coverage, more conditions being treated, higher prices and improved technology have been more important drivers of health spending (Byrant et al., 2004, 27-8).

The priorities of political parties and governments can change over time, and policy makers can respond to demographic and economic changes by modifying policy settings. For instance, during the 1980s housing expenditure became more targeted towards lower income deciles, and this continued during the 1990s. New Zealand Superannuation was income-tested between 1986 and 
Table 1: Percentage of households in each household type

\begin{tabular}{lrrrr}
\hline Household type & $\mathbf{1 9 8 8}$ & $\mathbf{1 9 9 8}$ & $\mathbf{2 0 0 7}$ & $\mathbf{2 0 1 0}$ \\
\hline Single & $20.6 \%$ & $21.9 \%$ & $22.6 \%$ & $22.6 \%$ \\
Couple no children & $24.4 \%$ & $25.8 \%$ & $25.8 \%$ & $26.3 \%$ \\
\hline Couple with children & $36.1 \%$ & $31.4 \%$ & $27.9 \%$ & $28.4 \%$ \\
Solo parents & $7.8 \%$ & $8.1 \%$ & $9.5 \%$ & $10.1 \%$ \\
\hline Other family types* & $6 \%$ & $8.4 \%$ & $7.3 \%$ & $6.1 \%$ \\
\hline Multi-family households** & $5.2 \%$ & $4.2 \%$ & $6.9 \%$ & $6.5 \%$ \\
\hline
\end{tabular}

*Other family types include one-family households where 'other' related and unrelated people are present.

**Multi-family households include two- or three-family households and any other multi-person households (e.g. flatmates).

Source: Statistics New Zealand Household Expenditure Survey and administrative data. Calculations by the Treasury.

Table 2: Government revenue and expenditure included in fiscal incidence research and attribution methods

\begin{tabular}{ll}
\hline Government revenue and expenditure areas & Attribution method \\
\hline Personal income tax & $\begin{array}{l}\text { HES surveys people on their income and Taxwell models tax } \\
\text { payments }\end{array}$ \\
\hline Goods and services tax & HES survey data on consumption \\
\hline Alcohol, tobacco and fuel excise duty & $\begin{array}{l}\text { HES respondents who reported consuming these products were } \\
\text { attributed the average amount of excise duty }\end{array}$ \\
\hline Pensions and benefits & $\begin{array}{l}\text { Taxwell models New Zealand Superannuation and six core income } \\
\text { support benefits using HES data. Other income support transfers } \\
\text { were also attributed }\end{array}$ \\
\hline Income-related rents & HES and HNZC data on household characteristics, income and region \\
HES dacation expenditure & $\begin{array}{l}\text { Compulsory education expenditure was largely attributed to those } \\
\text { age-eligible. Self-reports were used for income from student } \\
\text { allowances. Those who reported receiving an allowance were } \\
\text { attributed lower student loan write-offs }\end{array}$ \\
\hline
\end{tabular}

1998 (Preston, 2008, 16-19). During the early 1990 s core benefit levels were reduced and the universal Family Benefit abolished. In addition, during the 1990 s the age of eligibility for New Zealand Superannuation was gradually increased to 65 (Boston, 1999, 9, 13-15).

\section{Data and methods}

Data from the Household Economic Survey (HES) provide comprehensive survey information about income and expenditure by New Zealand's normally resident population living in private dwellings. The HES surveys several thousand households, and asks respondents to report their income over the previous 12 months. ${ }^{2}$ Sharing of resources by household members slightly declined from 2.8 people in 1988 to 2.6 in 2010.

Treasury's micro-simulation model, Taxwell, uses HES data to calculate how income taxes and cash benefits affect household income. Market and disposable income is equivalised to allow for the tendency for household expenses to grow with household size, but also for households to benefit from economies of scale. Households were placed into income deciles according to their equivalised household income, with decile 1 being the lowest income decile and decile 10 the highest.

To maintain comparability with Treasury's previous research, this study used a square root equivalisation scale. This gives a higher weight to children and to household economies of scale than were implicit in how New Zealand's income tax and cash transfers system modified market outcomes between 1995 and 2001. In other words, New Zealand's income tax and benefits system has made less allowance for children and for larger households than the equivalence scale used (Creedy and Sleeman, 2005, 9). Although household averages are shown, individuals are ranked by equivalised disposable income and then collected into ten equal sized groups of households.

Weighting HES data ensures that the sample data accurately match key characteristics of New Zealand's normally resident population. Examples of the characteristics used in the weighting are age, sex, ethnicity, household composition, home ownership and benefit status. However, the weighted HES data provided by statistics New Zealand is reweighted for use with Taxwell to ensure accurate understanding of the distribution of taxes and benefits expenditure.

Table 2 summarises how this study attributed government spending to households, and calculated the incidence on households of direct and indirect taxes. The 'cost of service' approach taken assumes that the value delivered to a household equals the cost of providing the service. The social insurance approach taken for health attributes expenditure is based on demographic data in the Ministry of Health's population-based funding formula for health boards. 
Figure 2: Average household market income by decile (\$2010)

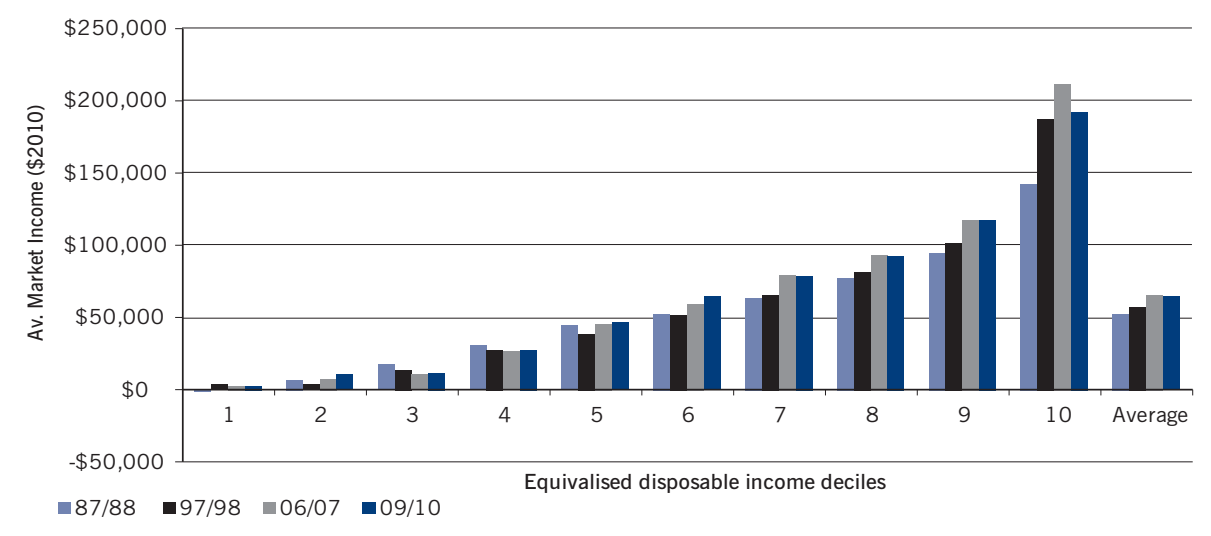

Figure 3: Average cost of income support received by a household in each decile (\$2010)

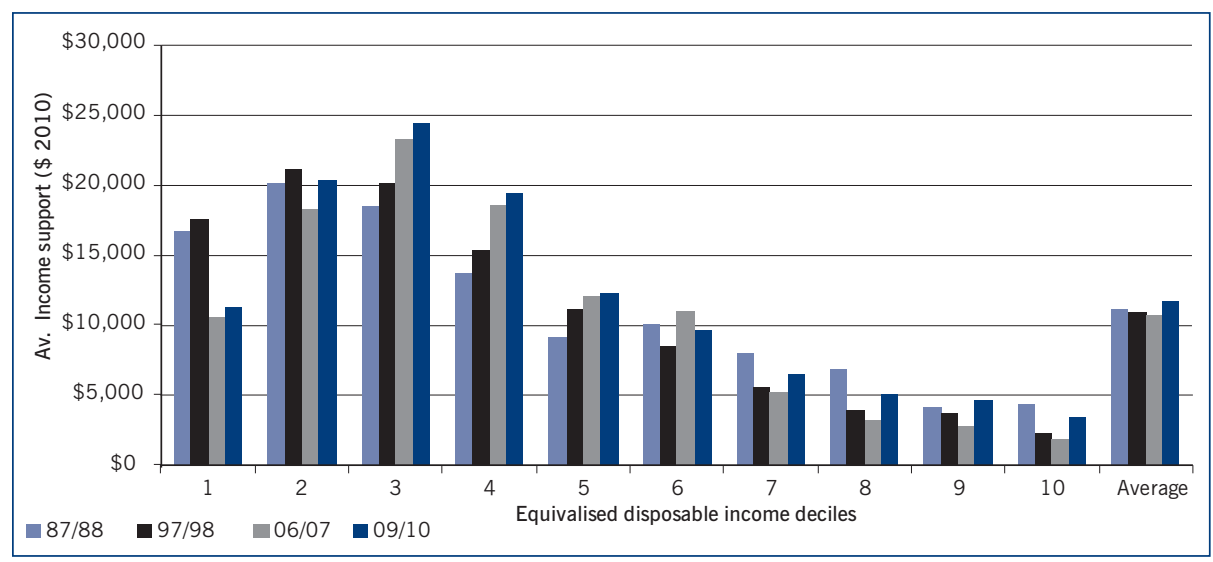

Approximately $70 \%$ of core Crown tax revenue and $67 \%$ of core Crown expenses in 2010 were included. Both percentages were slightly higher than in 2007, but comparable to the previous fiscal incidence study (Crawford and Johnston, $2004,10)$ and to recent fiscal incidence studies in Australia and Britain. Some expenditure is excluded because there is no clear theoretical basis for allocating government spending on public goods such as defence, law and order, and the environment. Since their incidence is unclear, corporate taxes are also usually excluded from fiscal incidence studies (Harding, Warren and Lloyd, 2006, 5). Because survey data are used, small changes in distributions are usually not statistically significant.

The decile 1 results need to be cautiously interpreted because, as in many other countries, reported income is 'not a reliable indicator' of these households' material living standards. This is because some households report implausibly low incomes or expenditure well above their income (Perry, 2011, 22).
Besides measurement problems, because people's incomes frequently fluctuate from year to year households sometimes draw on savings or borrow to smooth their consumption over time (Stillman et al., 2011, 3)

The market income results (Figure 2) are the first stage in analysing household income. Average real household market income was $\$ 64,400$ in 2010 , compared to $\$ 52,700$ in 1988 . Because of losses from self-employment, some households in the bottom decile have negative income. Between 1988 and 2007, the market incomes of deciles 1 to 5 were broadly static in absolute terms. However, there were substantial increases in market income for higher income deciles, and for decile 10 in particular. Between 2007 and 2010, market incomes for deciles 7 to 9 were largely unchanged. In contrast, decile 10 (down $\$ 19,000$ or $9 \%$ ) experienced a substantial decline in income. This was mainly due to lower self-employment earnings, probably resulting from the economic downturn

\section{Market income}

and the associated global financial crisis. The decline in market incomes for the top income decile in 2010 appears to have reversed a shift towards greater market income inequality in New Zealand. In 2010, the top income decile received $30 \%$ of market income compared to $27 \%$ in $1988,33 \%$ in 1998 and $32 \%$ in 2007.

\section{Income support expenditure}

Income support expenditure includes New Zealand Superannuation, income replacement benefits for workingage people, family assistance, housing subsidies and some additional assistance. Average per-household income support expenditure showed little change between 1988 and 2007 (Figure 3), before slightly increasing to $\$ 11,700$ in 2010. However, between 1988 and 1998 households in deciles 1 to 5 received higher income support expenditure, while absolute expenditure on deciles six to ten fell. Key factors included superannuation expenditure falling, but becoming more redistributive; greater targeting of housing assistance; and increased numbers of people on some means-tested income replacement benefits. The lowest household income decile has consistently received lower income support payments than deciles 2 and 3, and this difference has considerably increased since 1998. However, households in the lowest income decile often receive student allowances (which are counted here as education expenditure) or untaxed incomes (which have also been excluded), or underdeclare their incomes.

Because of the value of New Zealand Superannuation, in 2007 and 2010 no superannuitant couples or superannuitants living alone who received their full entitlement should normally be in decile 1 . The relative economic position of superannuitants improved between 2007 and 2010 (Figure 4), with indexing arrangements, tax cuts, increased labour market earnings and the economic downturn resulting in more superannuitants being in higher income deciles. Unlike in 1988 or 1998 there was no means-testing of superannuation in 2007 and 2010, although the age of eligibility was 65 compared to 60 in 1988 , and about 63 in 1998. In 2010, 66\% of 
New Zealand Superannuation went to households in the bottom five deciles, compared to $76 \%$ in 2007 . In contrast, in both 2007 and $2010,82 \%$ of expenditure on income replacement benefits went to people in households in deciles 1 to 5. Working for Families, and increases to these tax credits, have also primarily benefited lower income deciles, with $89 \%$ of this expenditure going to decile 1 to 5 households in 2010. The movement of superannuitants into higher income deciles in 2010 has slightly eroded the greater targeting that was evident in 1998, with the bottom five deciles receiving $70 \%$ of total income support expenditure in $1988,78 \%$ in $1998,77 \%$ in 2007 and $75 \%$ in 2010 .

\section{Income taxation}

Market income and many forms of income support are subject to income tax. Income tax rates fell and tax thresholds increased during the late 1980s and the 1990s. These income tax reductions, together with the static market incomes of deciles 1 to 6 , resulted in the average amount of income tax paid by deciles one to nine falling between 1988 and 1998 (Figure 5). However, the substantial increase in the market income of decile 10 resulted in this decile paying more income tax. The increase in the top marginal tax rate from $33 \%$ to $39 \%$, which came into effect in 2000, together with subsequent economic growth and fiscal drag contributed to some higher income deciles paying more income tax in 2007 than in 1998.

There were reductions in income tax thresholds from October 2008, followed in April 2009 by a decrease in the top marginal tax rate from $39 \%$ to $38 \%$, an increase in the second-band threshold, and the introduction of the independent earner tax credit. These income tax changes and the economic downturn reduced per-household income tax payments between 2007 and 2010, particularly for the top income decile. Although the results precede the October 2010 reductions in income tax, the average amount of income tax paid per household was $\$ 15,600$ in 2010 , compared to $\$ 17,600$ in 1988. The top income decile paid $34 \%$ of income tax in 2010, compared to $29 \%$ in 1988 .

Figure 4: Average cost of different types of income support received by households in each income decile in 2007 and 2010 (\$2010)

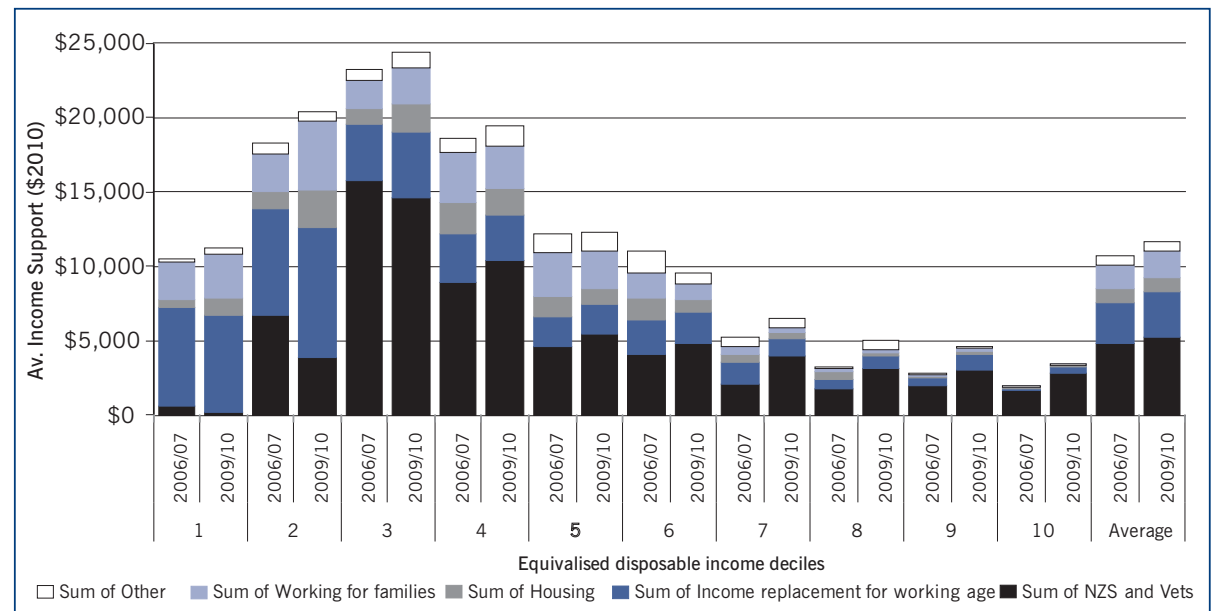

Figure 5: Average income (personal) tax paid by a household in each income decile (\$2010)

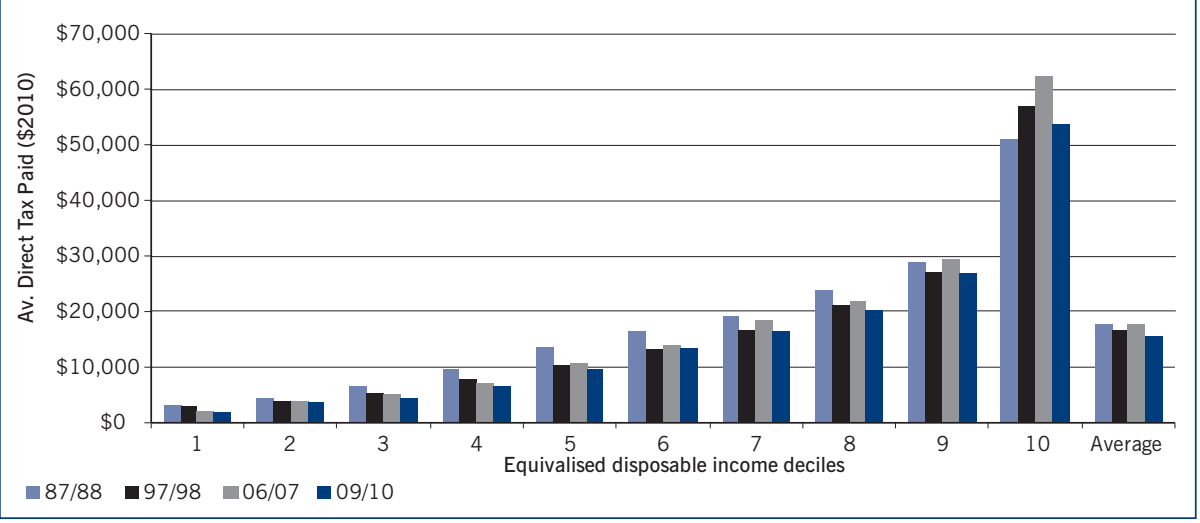

Figure 6: Average household disposable income by decile ( $\$ 2010)$

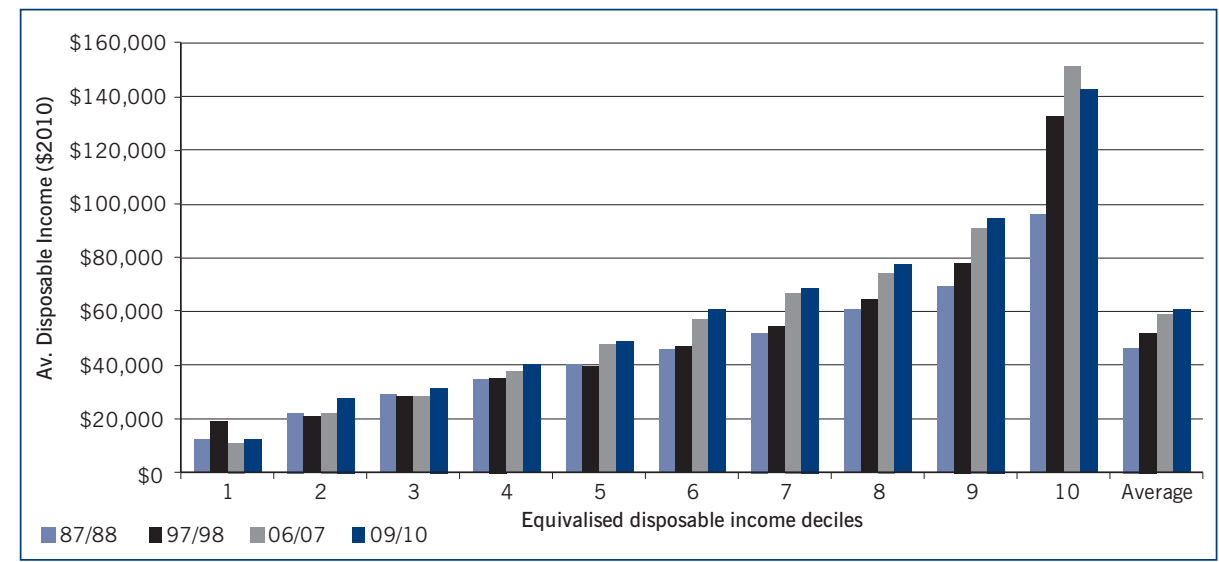

Disposable income

Disposable income is market income plus income support, less direct tax payments. Because of the redistributive effects of income support expenditure and direct taxes, disposable income is more equally distributed than market income. Average disposable household income in New Zealand has increased over time and was $\$ 60,500$ in 2010 (Figure 6). Although the biggest increases have been for the top decile, all deciles except decile 1 had higher disposable incomes in 2010 than in both 1988 and 1998. Between 2007 and 2010 the average disposable household income of deciles 1 to 9 increased because of income tax cuts and higher income support expenditure. The decline in the average disposable income of the top income decile between 2007 and 2010 reflected the substantial decline in market income received by this decile. 
Figure 7: Average cost of health services received by a household in each decile (\$2010)

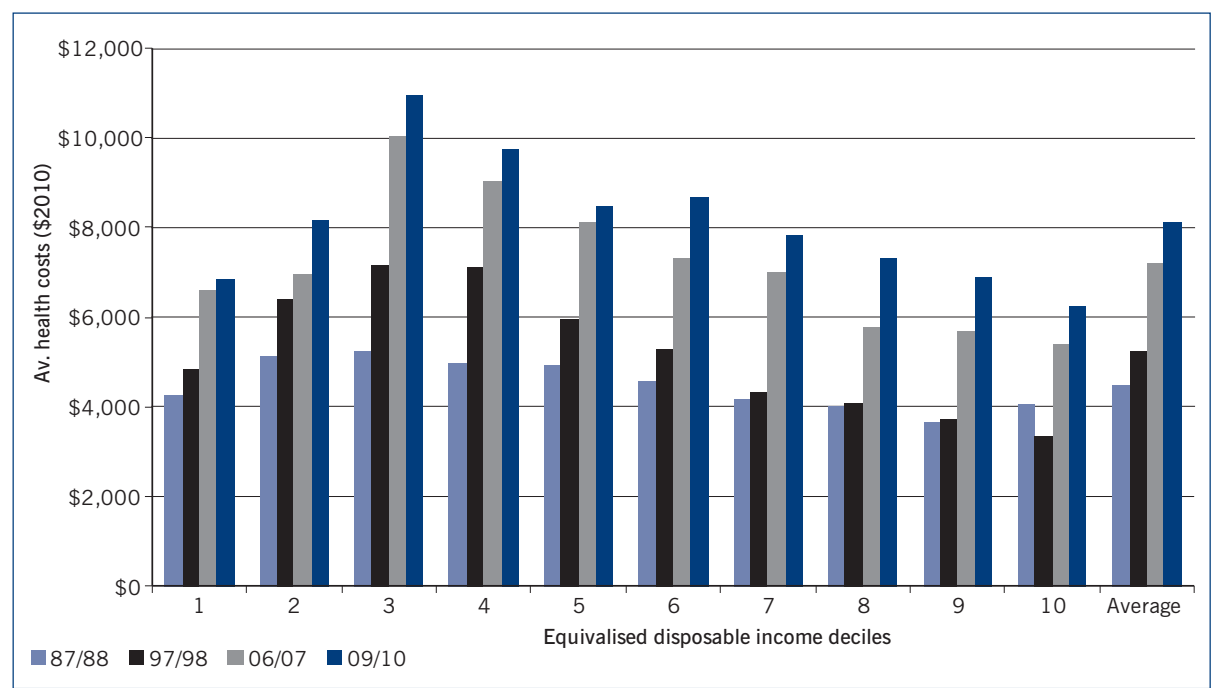

Figure 8: Average cost of education services received by a household in each income decile $(\$ 2010)$

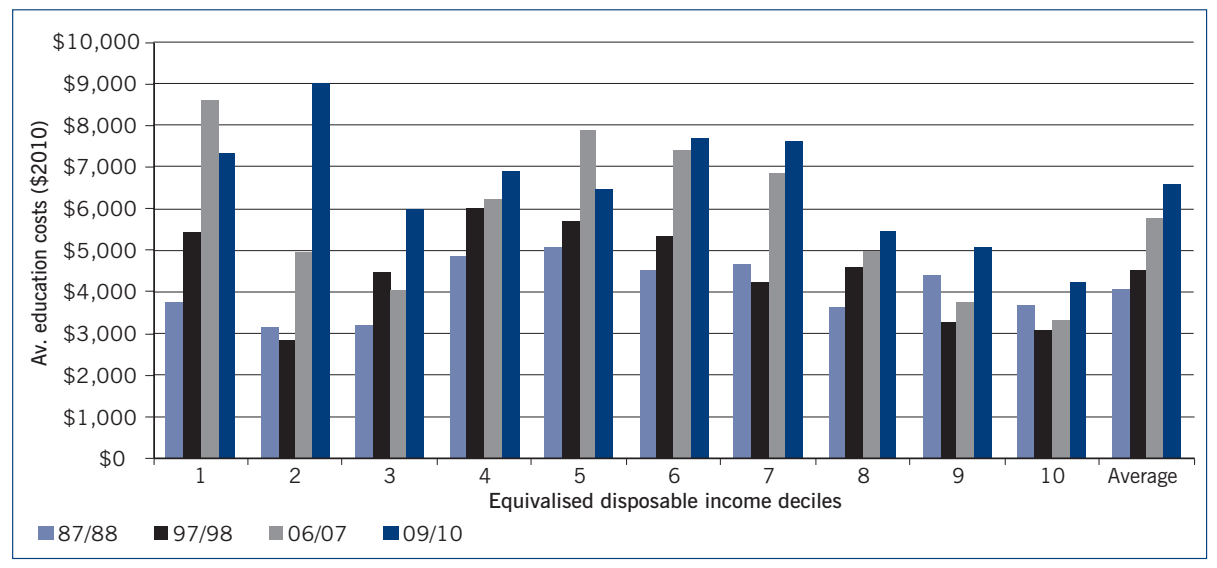

Most studies of household income cover only market and disposable income. However, this article now goes beyond these measures to study the distribution of health and education expenditure, and the incidence of indirect taxation.

\section{Health expenditure}

Health expenditure is attributed using the Ministry of Health's population-based funding formula, which is primarily based on age, but also includes gender, ethnicity and socio-economic status. This attribution assumes people benefit from having the right to use services, irrespective of whether they actually need to access them. Because health funding is highest for older age groups, the distribution of households containing superannuitants heavily influences the distribution of health expenditure. In 1988 and 1998, superannuitants were primarily in deciles 2 and 3, but in 2007 and 2010 the biggest concentrations were in deciles 3 increased since 1988, and the average perhousehold government subsidy of $\$ 8,100$ in 2010 was $80 \%$ higher in real terms than in 1988.

The share of health expenditure received by deciles 1 to 5 increased from $54 \%$ in 1988 to $60 \%$ in 1998. As with the income support results, this reflected greater targeting and a higher proportion of people from older age groups being in these deciles (Crawford and Johnston, 2004, 17). However, since 1998 health expenditure on higher income deciles has increased more quickly than health expenditure on lower income deciles. This has occurred because of higher expenditure on less targeted initiatives, such as the Primary Healthcare Strategy (launched 2001) which emphasises community health and health prevention, and because more older people are in higher income deciles. As a result, the combined share and 4. Health expenditure has consistently of spending on households in deciles 1 to 5 fell to $57 \%$ in 2007 and to $54 \%$ in 2010.

\section{Education expenditure}

The main recipients of education services are households containing children and young adults. The greatest concentrations of these households are at the beginning and middle of the income distribution. Most education expenditure is not targeted to particular income groups in New Zealand. Because most people directly benefit during childhood from compulsory education expenditure, this expenditure redistributes resources across people's lifetimes (Redmond, 2007, 12-13). Substantial increases in real education expenditure since 1988, to an average per-household subsidy of $\$ 6,600$ in 2010 , reflect a mixture of participation and cost increases.

The share of education expenditure received by households in deciles 1 to 5 increased from $49 \%$ in 1988 to $54 \%$ in each of the three following periods. The spike in education expenditure on decile 2 in 2010 reflects the movement of households containing couples with children from higher income deciles to lower income deciles since 2007. Education expenditure on deciles 3 and 4 was relatively low in 2007 and 2010 because superannuitants dominate these deciles.

Nevertheless, despite some tertiary students living away from their parents, $56 \%$ of tertiary education expenditure on providers and $58 \%$ of student loan initial fair-value write-down in 2010 went to students living in households in the top five income deciles. This partly occurs because the parents of tertiary students are often in their peak earning years (OECD, 2008, 231). In contrast, $64 \%$ of expenditure on student allowances in 2010 went to households in the bottom five income deciles. Because only student allowances to those aged under 24 were means tested against their parents' incomes in 2010, it is not surprising that some students in higher income households report receiving an allowance. Some low-income tertiary students also live in multi-family households with high household income. 


\section{Indirect taxation}

Figure 9 shows the average indirect tax paid by households in each decile. GST is the biggest source of indirect tax revenue, but indirect tax also includes excise duties on fuel, alcohol and tobacco. On average, households in higher income deciles pay a higher level and proportion of indirect tax than lower income households. Partly because of the 1989 increase in GST from $10 \%$ to $12.5 \%$, average per-household indirect tax payments increased from $\$ 5,900$ in 1988 to $\$ 6,400$ in 2010 .

Indirect tax payments reflect consumption patterns, and the results for the bottom three deciles suggest they have broadly similar levels of consumption of market goods and services. Indirect tax payments by the bottom three income deciles in 2010 were about $60 \%$ of the average for all households. This indicates that households in deciles 1 to 3 were able to purchase market goods and services at levels that were more similar to those of the average household than suggested by their disposable incomes (Figure 6).

\section{Final income}

Final income is disposable income plus the cost of in-kind social services received, but less indirect tax paid. It can be interpreted as a proxy for the economic resources available to households, and is a more complete measure than disposable income of the redistributive effects of government. Final income is more equally distributed than market and disposable income. For instance, whereas average market income for decile 10 in 2010 was approximately $\$ 193,000$, the average final income for this decile was about $\$ 142,000$. In contrast, whereas decile 4 had an average market income of about $\$ 27,500$ in 2010, the average final income of decile 4 was almost \$25,000 higher at \$52,200. Similarly, whereas decile 1 households reported an average market income of $\$ 2,900$ in 2010, their average final income was $\$ 22,700$, due to the effects of government intervention through taxes and spending.

Figure 10 indicates that final income was higher for all deciles in 2010 than in 1988. With the exception of decile one, all deciles had higher average final income
Figure 9: Average indirect tax paid by a household in each income decile $(\$ 2010)$

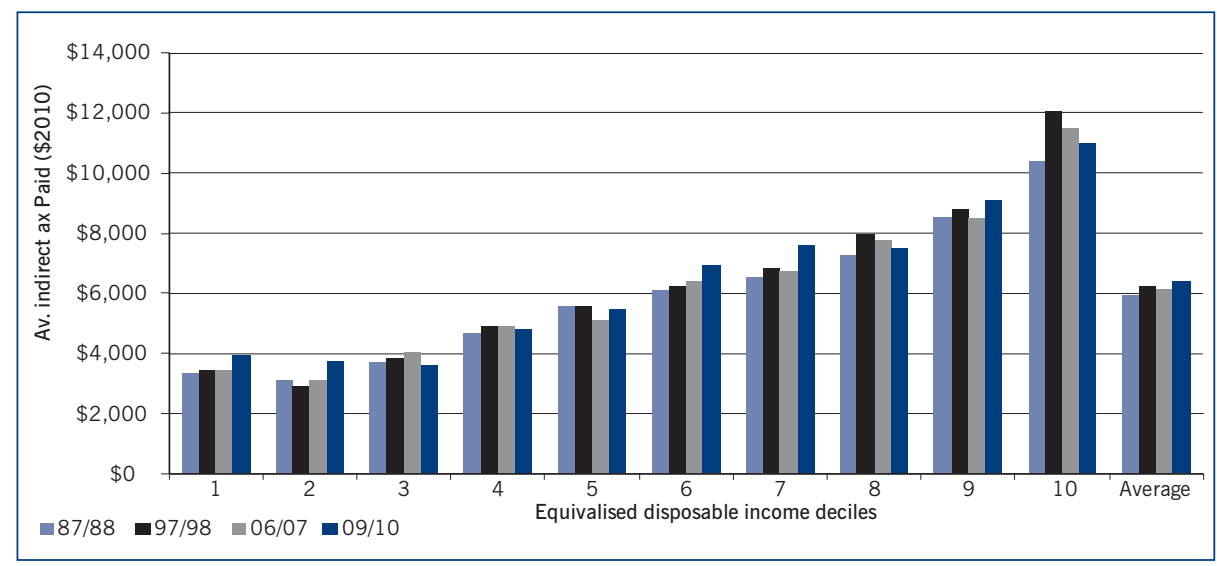

Figure 10: Average household final income by decile (\$2010)

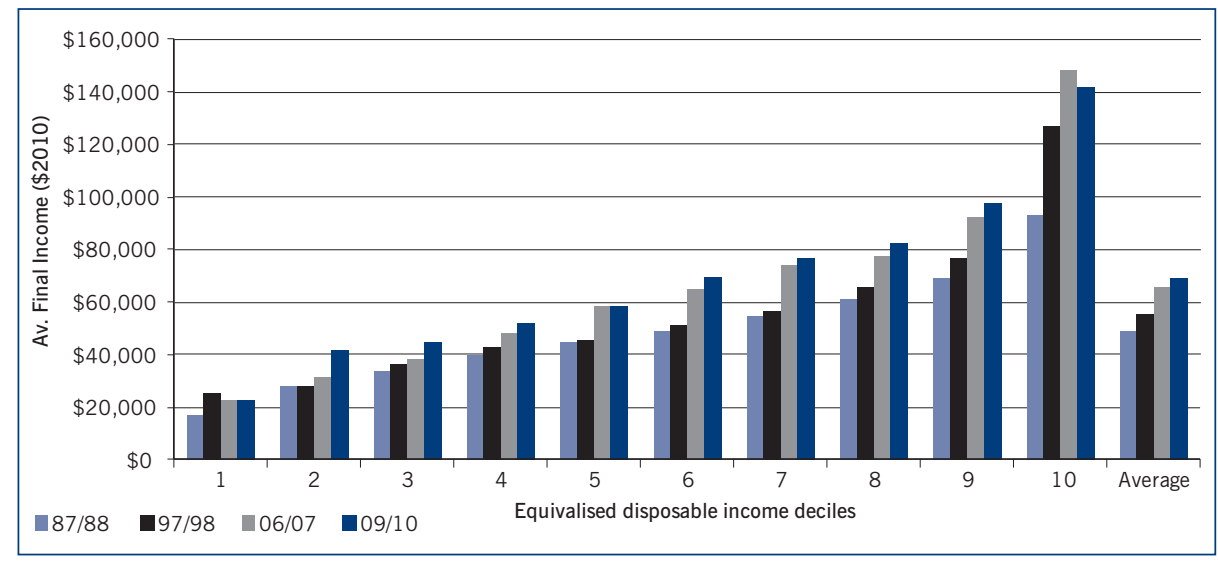

Figure 11 Net Fiscal Impact Average receipt of income support and social services less tax payments per household (\$2010)

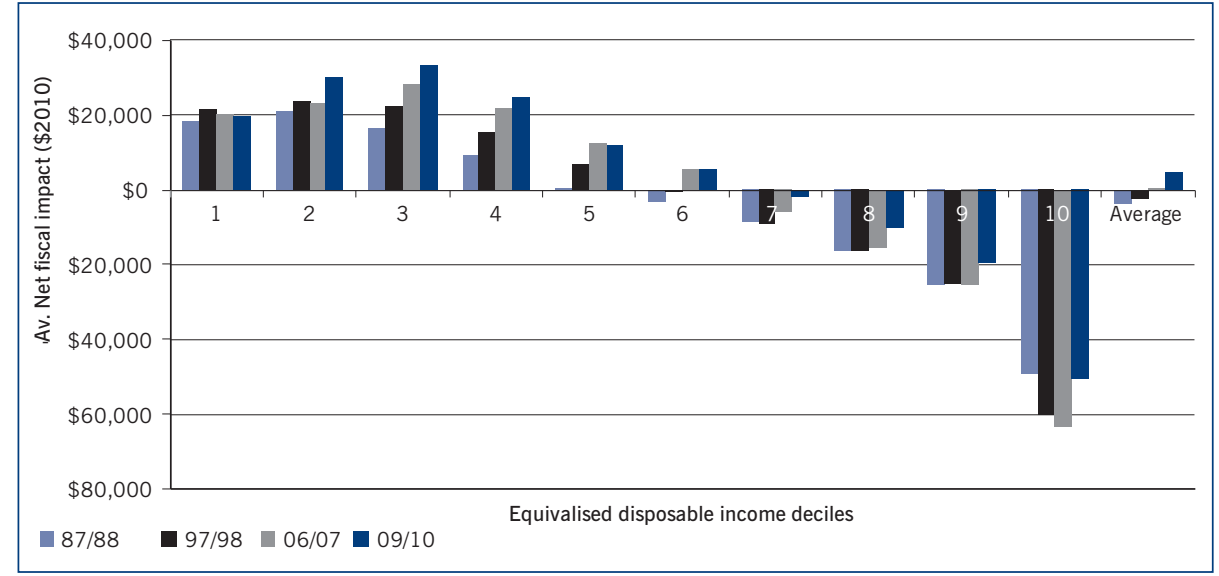

levels in 2010 than in 1998. Between 2007 and 2010, decile 10 stands out for being the only decile to receive substantially lower final incomes. This occurred because decile 10 experienced a much larger loss of market income than it gained from changes in taxes and spending. Higher final income for deciles 2 to 9 reflect a mixture of static market incomes, lower taxes, higher income support payments, and increased health and education expenditure.

\section{Net fiscal impact}

Figure 11 shows the average cost of income support, health and education expenditure less tax payments per household for each decile. This reveals the net impact of government redistribution on households' economic well-being. In all four time periods, deciles 1 to 5 received more government spending on the social services included in this study than they paid in taxes, while since 1998 decile 6 has also become a net fiscal recipient. In 
Table 3: Gini coefficient for different measures of household income

\begin{tabular}{lcccc}
\hline & $1988^{*}$ & $1998 *$ & 2007 & 2010 \\
\hline Market income & 0.42 & 0.49 & 0.54 & 0.52 \\
Disposable income & 0.30 & 0.35 & 0.38 & 0.36 \\
Final income & 0.27 & 0.30 & 0.35 & 0.33 \\
\hline
\end{tabular}

Source: Statistics New Zealand Household Expenditure Survey and administrative data. Calculations by the Treasury

*Crawford and Johnston's (2004) calculations

contrast, households in deciles 7 to 10 were consistently net contributors as they paid more tax, on average, than they received in social services. ${ }^{4}$ Similar net fiscal impact results occur in other countries, such as the United States (Chamberlain and Prante, 2007, 31).

Increases in the net fiscal gains for deciles 2 to 6 reflect the static market incomes, lower taxes, and higher income support, health and education expenditure these deciles experienced. Between 2007 and 2010, the average net fiscal impact increased from being about zero to $\$ 4,400$, because of lower taxes and higher health, education and income support expenditure.

\section{Impact on inequality measures}

The Gini coefficient measures inequality over an income distribution, with a higher Gini indicating higher inequality. Rows in Table 3 show the Gini coefficients for market, disposable and final income over time, while columns show the Gini coefficients in a particular year for each type of income.

Table 3 shows market income inequality grew between 1988 and 2007, with the Gini coefficient increasing from 0.42 in 1988 to 0.54 in 2007. Growing market income inequality, which increased by more in New Zealand than in most developed countries (OECD, 2008, 26-7), was a key cause of the increases in disposable and final income inequality that also occurred. However, between 2007 and 2010 the Gini for market income decreased from 0.54 to 0.52 , with this reflecting the substantial fall in market income experienced by decile ten. Partly because of the decline in market income inequality, the disposable income Gini decreased from 0.38 in 2007 to 0.36 in 2010 , while the final income Gini similarly fell from 0.35 to 0.33 .
The results confirm that income inequality is always lower for disposable than for market income, and that inequality is consistently lower for final income than for disposable income. For instance, Table 3 indicates that in 2010 the Gini coefficient for market income of 0.52 fell by $31 \%$ to 0.36 for disposable income, and by a further $9 \%$ (37\% compared to market income) to 0.33 for final income. This demonstrates the higher redistributive effects of the tax and transfers system than of in-kind transfers and indirect taxes.

Comparisons with results for other countries are difficult because of differences in the methodologies and coverage of fiscal incidence studies, and in what counts as government expenditure. For instance, Australia heavily relies on its tax system to redistribute money to middle- and upper- income families with children, to fund health and education expenditure, and to encourage retirement savings (Stebbing and Spies-Butcher, 2010). In contrast, New Zealand counts Working for Families tax credits and KiwiSaver subsidies as appropriated government expenditure, and has few other tax credits (Fookes, 2009, 3, 21-3; New Zealand Treasury, 2011). Nevertheless, the available data suggest that in all developed countries income tax and income support expenditure has more progressive redistributive effects on the Gini coefficient than in-kind health and education services (OECD, 2008, 42-4). Fiscal incidence studies for Australia, the United Kingdom and the United States also indicate that final income is also distributed more equally than disposable income in these countries (Chamberlain and Prante, 2007, 29; Harding, Warren and Lloyd, 2006, 16).
Limitations, caveats and further research

While this article provides fresh insights into the distributive effects of government taxation and expenditure, there are also several limitations. Because HES collects data on people over 12 months, the results provide only a static and partial picture of a household's standard of living. Income dynamics are obviously important, with lifetime earnings equality being higher than equality at a point in time (Barker, 1996, 5, 18). For example, many workingage New Zealanders (and for some age groups the majority) have been dependent on a benefit at some stage, although a minority of beneficiaries account for most time spent on benefits (Welch and Wilson, 2010, 4, 18-19). Today's high-income households will frequently have received substantial benefits, such as education services, from the government in earlier years and will receive substantial health services and superannuation payments when household members are retired.

Externalities, such as the gain to society from having a healthy and welleducated population, have also not been considered (OECD, 2008, 226). In addition, expenditure on public goods such as defence and the environment has not been included. Similarly, some types of income are excluded. For instance, superannuitants often own substantial housing assets, and consumption-based measures of living standards indicate that relative few elderly New Zealanders experience hardship (Perry, 2010). Statistics New Zealand is currently investigating the quantification of economic benefits derived from owneroccupied housing.

The 'cost of service' approach used means that increases in social services expenditure may not have always resulted in commensurate improvements in people's well-being. This is because our method measures inputs rather than quantifying in-kind service outputs. For instance, higher teachers' salaries may only gradually improve teacher quality. Similarly, health costs per output for medical and surgical services, which are a measure of efficiency, increased by $27 \%$ in real terms between 2002 and 2008 (Ministry of Health, 2009, 116). Because of our input approach, 
a reduction in education and health expenditure could affect the final income Gini coefficient, but would not decrease people's well-being providing efficiency gains maintained service levels. Statistics New Zealand is currently exploring ways of better quantifying public sector output in New Zealand (Statistics New Zealand, 2010c, iii).

Finally, the causes of changes in income distribution, government expenditure and taxation are complex, and identifying them is difficult and limited by data availability. While the reasons for some changes can be identified this is not always possible. Only some changes result from policy changes.

\section{Conclusion}

This article has used new data from 2007 and 2010 to compare the redistributive effect of government expenditure and taxation on the economic position of New Zealand households in 1988, 1998, 2007 and 2010. As well as including results on standard measures of market and disposable income, this article has also examined changes in the effect of in-kind social spending and of indirect taxation on households' circumstances. While using the most up-to-date data available, the results precede the October 2010 reductions in income tax and increase in GST.

Market incomes have increased for deciles six to ten, although between 2007 and 2010 the economic downturn and the global financial crisis reduced market incomes for the top income decile. Usually only decile 10 has experienced an increase in its tax burden, although the fall in market income for decile 10 in 2010 meant that this decile was also paying less tax. Income support expenditure has benefited lower income deciles most, although the redistributive effects of spending have varied and been affected by the level of targeting, the age of eligibility for superannuation, and the mix of spending. Disposable income, which is market income plus income support but less direct taxation, was higher in 2010 than in 1988 and 1998 for all deciles except decile 1.

Health and education expenditure have substantially increased since 1988, and have increased the consumption possibilities of all household income deciles. Final income, which is disposable income plus health and education expenditure but less indirect taxation, has been considerably more evenly distributed than market income, and has increased for almost all income deciles. Over the years covered, households in deciles 7 to 10 have consistently paid more in tax than they have received in income support payments and in health and education services. Nevertheless, income inequality increased in New Zealand until 2007, irrespective of the income measure used, although the economic downturn since 2008 seems to have reduced this tendency.

\footnotetext{
Access to data used in this study was provided by Statistics New Zealand under conditions designed to give effect to the security and confidentiality provisions of the Statistics Act 1975. Results presented in this study are the work of staff at the New Zealand Treasury and not Statistics New Zealand. The views, opinions, findings and conclusions of this article are strictly those of the authors and do not necessarily reflect the views of the New Zealand Treasury.

2 The full HES, which includes expenditure, is currently conducted triennially.

3 The results precede the October 2010 GST increase.

4 The results will vary for individual households. This is particularly true for government education and health expenditure because entitlements in these areas are not usually linked to household income.
}

\section{References}

Australian Bureau of Statistics (2007) Government Benefits, Taxes and Household Income, Canberra: Australian Bureau of Statistics

Barker, G. (1996) Income Distribution in New Zealand, Wellington: Institute of Policy Studies

Barnard, A. (2009) 'The Effects of Taxes and Benefits on Household Income, 2007/08', Economic and Labour Market Review, 3 (8), pp.56-66

Boston, J. (1999) 'New Zealand's Welfare State in Transition', in J. Boston, P. Dalziel and S. St John (eds), Redesigning the welfare state in New Zealand:pProblems, policies, prospects, Auckland: Oxford University Press

Byrant, J., A. Teasdale, M. Tobias, J. Cheung and M. McHugh (2004) Population Ageing and Government Health Expenditures in New Zealand, 1951-2051, working paper 04/14, Wellington: The Treasury

Chamberlain, A. and G. Prante (2007) Who Pays Taxes and Who Receives Government Spending? An analysis of federal, state and local government tax and spending distributions, 1991-2004, Washington: Tax Institute

Crawford, R. G. and Johnston (2004) Household Incomes in New Zealand: the impact of the market, taxes and government spending, 1987/88-1997/98, Wellington: New Zealand Treasury
Creedy, J. and C. Sleeman (2005) 'Adult Equivalence Scales, Inequality and Poverty', New Zealand Economic Papers, 39 (1), pp.51-83

Department of Statistics (1990) The Fiscal Impact on Income Distribution 1987/88, Wellington: Department of Statistics

Fookes, C. (2009), Spending Through the Tax System: tax expenditures, Wellington: New Zealand Treasury

Harding, A., R. Lloyd and N. Warren (2006) 'The Distribution of Taxes and Government Benefits in Australia', in D.B. Papadimitriou (ed.), The Distributional Effects of Government Spending and Taxation, Basingstoke: MacMillan

Harding, A., N. Warren and R. Lloyd (2006) Moving Beyond Traditional Cash Measures of Economic Well-being: including indirect benefits and indirect taxes, Canberra: NATSEM: National Centre for Social and Economic Modelling

May, H. (2009) Politics in the Playground: the world of early childhood in New Zealand, Dunedin: Otago University Press

Ministry of Health (2009) Annual Report for the Year Ended 30 June 2009, Wellington: Ministry of Health

Ministry of Social Development (2011) The Statistical Report for the Year Ending 30 June 2010, Wellington: Ministry of Social Development

New Zealand Treasury (2011) 2011 Tax Expenditure Statement, Wellington: New Zealand Treasury 
The Effect on Household Income of Government Taxation and Expenditure in 1988, 1998, 2007 and 2010

OECD (2008) Growing Unequal? Income distribution and poverty in OECD countries, Paris: OECD

Perry, B. (2010), Non-Income Measures of Material Wellbeing and Hardship: first results from the 2008 New Zealand Living Standards Survey with international comparisons, working paper 01/09, Wellington: Ministry of Social Development

Perry, B. (2011) Household Incomes in New Zealand: trends in indicators in inequality and hardship 1982 to 2010, Wellington: Ministry of Social Development

Preston, D. (2008) Retirement Income in New Zealand: the historical context, Wellington: Retirement Commission

Redmond, G. (2007) Changing Patterns of Resource Transfers Across the Lifecycle: Australia since the 1980s, Sydney: University of New South Wales

Snively, S. (1986) 'Evaluating the Budget's Distributive Influence on Household Incomes', MA thesis, Victoria University of Wellington

Statistics New Zealand (2010a) 'Demographic trends: 2010, 2011', http://www.stats.govt.nz/browse_for_stats/population/estimates_and_ projections/demographic-trends-2010.aspx
Statistics New Zealand (2010b) Household Economic Survey: year ended June 2010 - hot off the press, Wellington: Statistics New Zealand

Statistics New Zealand (2010c) Measuring Public Sector Productivity in New Zealand: a feasibility study, Wellington: Statistics New Zealand Stebbing, A. and B. Spies-Butcher (2010) 'Universal Welfare by "Other Means"? Social tax expenditures and the Australian dual welfare state', Journal of Social Policy, 39 (04), pp.585-606

Stillman, S., T. Le, J. Gibson, D. Hyslop and D. Mare (2011) The Relationship Between Individual Labour Market Outcomes, Household Income and Expenditure, and Inequality and Poverty in New Zealand from 1983 to 2003, Wellington: Statistics New Zealand

Welch, D. and M. Wilson (2010) Lifecourse Factors Associated with Time Spent Receiving Main Benefits in Young Adulthood: full report on early findings, Wellington: Ministry of Social Development

Welfare Working Group (2011) Reducing Long-term Benefit Dependency: recommendations, Wellington: Welfare Working Group

\section{FUTURE STATE Directions for Public Management in New Zealand} Edited by Bill Ryan \& Derek Gill

New Zealand's public sector has consistently rated well internationally on a variety of measures of comparative government performance. In the 1980s New Zealand achieved a step change in public sector reform when it introduced a distinctive and widely applauded model of public management. Despite attempts at continuing improvement, however, New Zealand has struggled over the past decade to keep developing the frameworks and tools that public managers require to manage efficiently and effectively in the public sector. New Zealanders are becoming more diverse in their needs, ethnicities and lifestyles, and more demanding their expectations, and the weight of these expectations increasingly impacts on government. In the face of these changing circumstances, it is tempting to stick with the current model and continue to refine and adjust it. But tweaking is no longer enough another step change is required.

In 2001 the chief executives of several public sector organisations commissioned a group of researchers associated with the School of Government at Victoria University of Wellington to undertake a project looking at the 'future state' - to consider present trends that would impact on public management in coming years. Future State pulls together the results of the work, covering emerging trends in governance, from both New Zealand and international perspectives: issues, options and policy implications of shared accountability; experimentation and learning in policy implementation; agency restructuring; skills and capability; the authorising environment; and e-government. It contains valuable insights into how New Zealand's public sector currently operates, and how it might operate in the future.

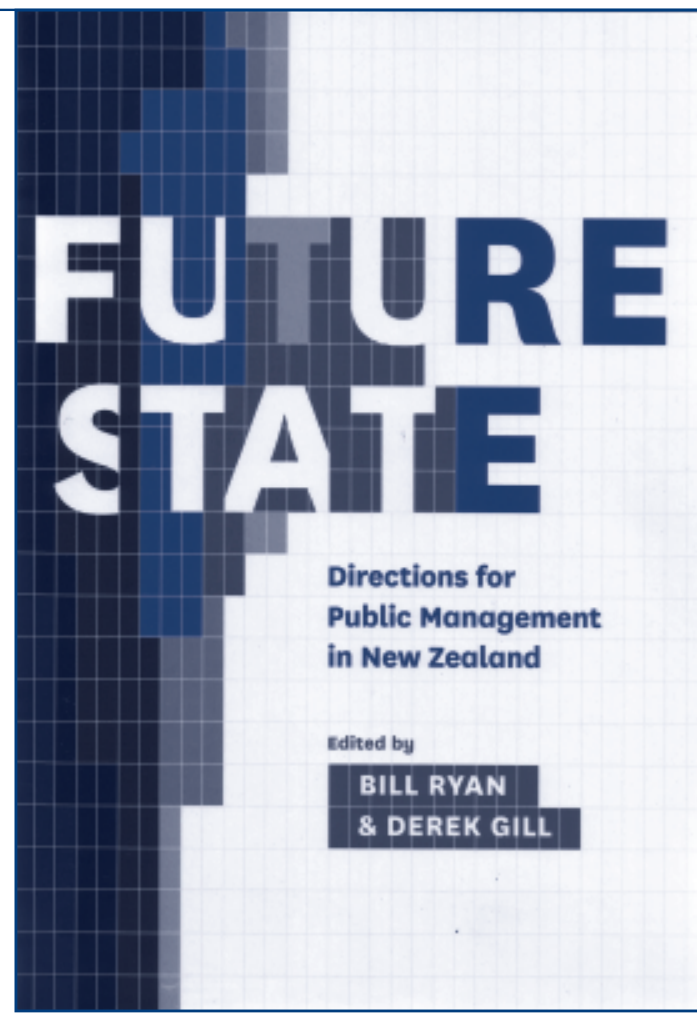

A Victoria University Press Publication

By Bill Ryan \& Derek Gill

Publication Date: December 2011

Format B5 Paperback, pp 348

ISBN 978-1-86473-820-2 Price - \$50

(including P\&P within New Zealand)

To order go to Victoria University Press website

http://www.victoria.ac.nz/vup/2011titleinformation/future.aspx

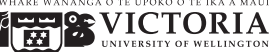

VICTORIA UNIVERSITY PRESS 